\title{
Impact of the global crisis caused by the coronavirus pandemic on the socio-economic development of the Republic of Uzbekistan
}

Tuychiev Inoyatillo ${ }^{1}$

\author{
${ }^{1} 3^{\text {rd }}$-year student at "Silk Road" International University of Tourism. \\ E-mail: inoyat.tuychiev@gmail.com
}

\begin{abstract}
Since the start of 2020, a new type of respiratory virus, referred to as Covid19, has been shaking the world's economy to its cores. It has been proven that regardless of the income level, any existing economy fails to combat unprecedented economic challenges caused by this novel coronavirus. The paper analyses the impact of the global crisis caused by coronavirus pandemic on different socioeconomic sectors of the Republic of Uzbekistan.
\end{abstract}

Keywords: Covid19, Economic impact, coronavirus, Uzbekistan, GDP, economic challenges, foreign economic activity, tourism, textile, clothing, the auto industry.

\section{Introduction}

Unprecedented measures are being taken around the world to combat the spread of coronavirus infection, for example, by restricting the movement of people and closing businesses. As a result, the world's largest economies are experiencing a sharp decline in production and consumption, disruption to global value chains and trade relations, falling commodity prices in global financial markets, and deteriorating conditions.

These factors also affect the economy of Uzbekistan, which is part of the global economic system, which, in turn, requires the adoption of effective preventive measures to mitigate the negative consequences of this situation. At the same time, special attention is paid to supporting and ensuring the sustainability of rapidly growing economic sectors such as tourism, transport, pharmaceuticals, and textiles[1].

President of the Republic of Uzbekistan Shavkat Mirziyoyev, in his address to the people of Uzbekistan, emphasized that the coronavirus pandemic, as in all countries of the world, will naturally hurt the economy of Uzbekistan. (sputnik.uz, 2020)

The President noted that as a result of a sharp drop in world oil prices (from $\$ 60$ to almost $\$ 30$ per barrel), revenues from our gas exports might decrease. Devaluation of the national currencies of Uzbekistan's main foreign trade partners can reduce foreign exchange earnings to the Republic.

While it is impossible to accurately predict the socio-economic damage caused by the global (COVID-19) coronavirus pandemic, there is a general consensus among economists that this will have a negative impact on the global economy and living standards. The economic damage caused by the coronavirus pandemic is mainly related to the decline in demand, that is, the inability of consumers to purchase affordable goods and services. These losses are particularly evident in areas of the service sector that have been severely affected, such as airlines and tourism, hospitality and catering, and cultural entertainment. The same negative impact applies to other industries[2].

Due to the coronavirus pandemic, five areas of activity are at risk, representatives of which may lose their jobs. So, without sources of income, air carriers, builders, machine builders, catering, and tourism industry workers may remain. At the end of 2020, the Central Bank of Uzbekistan also expects a slowdown in the growth rate of the country's gross domestic product (GDP) to $1.5-2.5 \%$ amid the coronavirus pandemic.

\section{Foreign economic activity.}

At the end of 2019, Uzbekistan's GDP amounted to \$ 57.9 billion. (in 2018 - \$ 50.4 billion), and GDP per capita amounted to $\$ 1,724$ and increased by 3.6\%. At the same time, the GDP growth rate in Uzbekistan in 2019 constituted $5.6 \%$ (in $2018-5.1 \%$ ), which is more than two times higher than the global GDP growth rate (2.3\% in 2019). (stat.uz, 2020)

Moreover, at the end of 2019, Uzbekistan's foreign trade turnover amounted to $\$ 42.2$ billion, of which exports \$ 17.9 billion, imports $\$ 24.3$ billion, and the foreign trade balance or net export has a negative value in 6.4 billion dollars, which accordingly reduced the country's GDP by this amount. At the end of 2019, Uzbekistan's foreign trade turnover amounted to $\$ 42$ billion.

In this regard, one of the essential government tasks is to stimulate the export activities of economic entities, especially the non-resource sector of the economy, the development of which is given priority in many developing countries as the main factor contributing to economic growth.

Currently, more than $50 \%$ of the total and more than $60 \%$ of commodity exports (excluding services) of Uzbekistan are raw materials (gold, natural gas, non-ferrous metals, cotton fiber,) which indicates the raw material dependence of the economy, which can be negatively reflected on economic growth[3]. 


\section{MIDDLE EUROPEAN SCIENTIFIC BULLETIN}

At the same time, almost $45 \%$ of imports consist of machinery and equipment that are used to create and modernize production facilities, which in the long term will contribute to economic growth, including an increase in exports of finished products.

\section{Exports with high added value.}

In his speech at a joint meeting of both chambers of the Oliy Majlis on January 21, 2020, the President set a new bar - within five years to bring the annual export volume to $\$ 30$ billion, while, in particular, it is envisaged to increase export volumes: (review.uz, 2020)

- fruit and vegetable products up to at least $\$ 5$ billion by 2025

- textile and leather and footwear industry up to 8 billion dollars. by 2025 , for which to increase the volume of production of products with high added value by 4-5 times;

- electrical products up to 500 million US dollars. by 2022, why increase the production of household appliances, industrial electrical appliances, cable products and this year to increase production by 1.5 times;

- cars at least 100 thousand by 2023, for which to increase the production of cars and trucks, as well as buses up to 360 thousand units per year;

- medicines up to USD 100 million. In the next five years and to increase the share of domestic pharmaceutical products in the domestic market from $45 \%$ to $70 \%$.

At present, from the number of finished products produced in Uzbekistan, the most substantial volumes in total exports are textiles $-9.1 \%$, as well as food products $-8.5 \%$ (mainly fruits and vegetables $-6.7 \%$ ). Also, the potential for increasing exports has the products of automotive, electrical, leather and footwear, and some other industries.

\section{Export markets of Uzbekistan.}

In the foreign trade turnover of Uzbekistan, which at the end of 2019 grew by $25.2 \%$ and amounted to 42.2 billion dollars, the largest share was taken by China $-18.1 \%$, Russia $-15.7 \%$, Kazakhstan - 8.0\%, Republic of Korea - $6.5 \%$, Turkey $-6.0 \%$, Germany $-2.3 \%$ and Kyrgyzstan $-2.0 \%$.

Exports also grew by $28.0 \%$ and amounted to $\$ 17.9$ billion, the main trading partners for exports were: China 14.0\%, Russia - 14.0\%, Kazakhstan - 8.0\%, Turkey - 6, 7\%, Kyrgyzstan 3.8\%, Afghanistan 3.4\%, and Tajikistan 1.9\%[4].

The need for active interaction.

In world trade, the World Trade Organization (WTO) establishes uniform rules that promote maximum liberalization and reduce barriers to mutual trade between member countries. At the same time, individual WTO member countries go further and create economic associations in which complete freedom of trade is ensured without any barriers, an example of which is the European Union, MERCOSUR in Latin America, ASEAN in Asia, the Cooperation Council for the Arab States of the Gulf, in the CIS space - the Eurasian Economic Union.

Since 2013, Uzbekistan has been a party to the CIS Free Trade Area (FTA) Agreement (also includes Armenia, Belarus, Kazakhstan, Kyrgyzstan, Tajikistan, Ukraine, Russia, Moldova). At the same time, Uzbekistan joined the Treaty with several exemptions to protect the internal market (in particular, Uzbekistan does not provide national treatment in trade to other parties to the Treaty, and also maintains the procedure for resolving disputes based on bilateral negotiations).

The exemptions expire at the end of 2020 or from the date of Uzbekistan's accession to the WTO (whichever comes first), after which all provisions of the CIS FTA will also apply to Uzbekistan. Thus, from the beginning of 2021 , Uzbekistan, under the CIS FTA, will find itself in a more robust competitive environment with trading partners under the CIS FTA. At the same time, it should be noted that all countries of the CIS FTA are WTO members (except Belarus, which plans to join the WTO this year), and five of them (Armenia, Belarus, Kazakhstan, Kyrgyzstan, and Russia) are also members of the EAEU[5].

In this regard, the participation of Uzbekistan, both in the WTO and closer interaction with the EAEU, can contribute to the expansion of opportunities for the export of domestic finished products to foreign markets. At the same time, expanding the access of domestic goods to the markets of the EAEU countries and opening the domestic market for producers of the countries of the union will help accelerate the adaptation of domestic businesses to work in a more competitive environment.

Retail trade services.

The COVID-19 epidemic has also impacted the retail industry around the world. Goods from China, according to the Central Bank of the Republic of Uzbekistan, occupy a tangible place in the consumer basket of the Republic, and a decrease in imports puts pressure on prices. (cbu.uz, 2020)

As countries around the world come under quarantine measures, and consumers around the world begin to avoid contact with people, retailers in Uzbekistan, as well as around the world, are trying to adapt and find a way out of this situation. They acknowledge that the global response to the new COVID-19 virus will have a tangible impact on their business as the world changes every day[6].

However, while some retailers see a drop in demand for certain products, others are facing an unprecedented surge in demand. In particular, grocery retailers are faced with a significant lack of products that are in the highest demand.

Many retailers today analyze their overall financial stability in various scenarios and, if necessary, attract lenders to refinance loans or amend financial conditions that may be affected.

However, at the same time, in our opinion, the spread of this virus brings not only problems but also certain 


\section{MIDDLE EUROPEAN SCIENTIFIC BULLETIN}

opportunities. Under quarantine conditions, people around the world have turned to online ordering services. The coronavirus epidemic could change industries and behaviors not only for companies around the world but also for consumers. Online shopping is likely to become a long-term phenomenon.

For example, the number of online orders in the services of Uzbekistan has increased several times. LeBazar (an online store) had to hire new people, as the number of requests for placing orders increased several times, and the demand for food delivery in the Express 24 marketplace grew by 500\%. During the quarantine period, the Makro retail chain also launched an online food delivery service. All deliveries are delivered, taking into account sanitary and hygienic requirements.

The sphere of tourism.

The magnitude of the damage done to global tourism by COVID-19 is reflected in a new World Tourism Organization (UNWTO) report on travel restrictions. Since January 2020, almost all global routes have been restricted to travel, including a complete travel ban, according to a report released during a period of severe disruption to the sector. As of April 6, 2020, 96\% of global travel destinations have imposed severe travel restrictions in response to the pandemic. People do not travel in the world of tourism. So far, about 3 billion people are in isolation. About 75 million jobs were lost in global tourism[7].

Also, this pandemic will undoubtedly affect the tourism sector in Uzbekistan. A decrease in the number of foreign tourists and a decrease in receipts from their service is also possible. All this cannot but affect the gross domestic product and the volume of exports. In Uzbekistan alone, about 45,000-50,000 bookings have been canceled. The question of how travel agencies should now cover themselves needs an answer. The question of how to get out of this situation after a pandemic is severe. Besides, at the initiative of the State Committee for Tourism Development of the Republic of Uzbekistan, significant work is underway in our country to develop the industry, as well as to turn this sector into a locomotive for other sectors of the economy. The chairman of the committee A. Abdukhakimov noted that onlinetourism.uz had been launched, which allows virtual tourism in the country, as well as start-up projects in the field of tourism after the end of the quarantine period, including innovative business ideas, especially for young people and their tourists.

Automotive industry.

The global auto industry is facing significant challenges due to the worldwide coronavirus epidemic.

The pandemic and related quarantine did not significantly affect the results of the automotive industry in Uzbekistan in the first quarter, but in the second quarter, the impact will be much more severe.

So in the Republic of Uzbekistan for the first quarter of 2020, 75,635 cars, 943 buses and ISUZU trucks, 106 MAN and Sinotruck trucks, and 271 KamAZ trucks were produced. The market of spares and parts in Uzbekistan is estimated at $\$ 500$ million. However, the share of locally produced products in this market is only $9 \%$. The joint-stock company Uzavtosanoat has been tasked with ensuring localization of 300 types of components imported from abroad by the end of the year and organizing their production with a quality that is not inferior to foreign analogs.

\section{Textile and clothing.}

Possessing competitive advantages in the textile industry, Uzbekistan aims not only to mitigate the impact of the pandemic on the industry but also to enter new sales markets.

The textile and clothing and knitwear industries are strategically crucial for the country's economy. These sectors account for $12 \%$ of the total industrial production and $15 \%$ of the manufacturing industry. The industries employ 365 thousand people. Exports last year amounted to $\$ 1.6$ billion, having almost doubled over the past three years.

At the same time, as the President noted during a meeting on April 23, given that our country is one of the largest cotton producers in the world, there remains vast untapped potential for the further development of these industries, increasing exports, and providing employment for more than 3 million people.

Meanwhile, this industry sector is currently facing several difficulties, both systemic and caused by the coronavirus pandemic. Considering the importance and potential of the textile and garment and knitwear industries for economic development, the country is taking active measures to address them[8].

As in the rest of the world, light industry enterprises in Uzbekistan face several problems in their current activities caused by the spread of the coronavirus. COVID-19 disrupts trade chains, and other countries are forced to introduce increased security measures when passing goods across borders, the suspension of production leads to a reduction in the supply of consumer and industrial goods. Currently, among the main problems of domestic manufacturers of light industry sectors, the following stand out:

1) Falling demand in the domestic and foreign markets for most of the products (not counting those produced for medical purposes).

2) Temporary production downtime due to quarantine measures. In particular, the suspension of transport in cities, restrictions on movement between cities lead to difficulties for workers to get to workplaces.

3) Termination and / or delays in the supply of raw materials and components used in the manufacture of light industry products. In particular, China is one of the largest suppliers of raw materials and components for the production of light industry in Uzbekistan, where many productions were suspended. Also, the introduction and tightening of sanitary inspections in transit countries lead to delays in cargo, which, in turn, can lead to production downtime. 


\section{MIDDLE EUROPEAN SCIENTIFIC BULLETIN}

The branches of the light industry of Uzbekistan are fully provided with the necessary production of raw materials. However, the production of products with high added value also requires the use of materials and components that are not currently produced in the country or do not have sufficient production volumes to meet the demand of manufacturers.

For example, these are products of the chemical industry (adhesives, dyes), chemical and synthetic threads, fibers, fabrics, footwear, haberdashery accessories. In this connection, the Republic is actively importing these goods, and most of the import falls on China. At the same time, according to data presented on the website comtrade.un.org, imports for the first two months of this year of chemical, synthetic threads, fibers, fabrics from the PRC decreased very slightly from $\$$ 9.8 million in January-February 2019 to 9.6 million dollars for the same period of the current year. Total imports (TN VED groups 41-43, 51-64) from China of products of the industries under consideration decreased from $\$ 25.8$ million to $\$ 22.8$ million. Imports of the same goods from all countries decreased from $\$ 50.2$ million. dollars to 47.6 million dollars.

4) A decrease in sales and, accordingly, the income of enterprises lead to overstocking of products, a shortage of working capital, and difficulties with the payment of wages, taxes, and payments on loans.

5) Difficulties in the implementation of investment projects created jointly with foreign investors and dependent on the supply of equipment not produced in the Republic from abroad, as well as the arrival of foreign specialists in the country.

6) Difficulties with the transportation of finished products, raw materials, semi-finished products during export. As noted in the Uztekstilprom Association, the enterprises of the industry are facing export problems due to a sharp increase in the cost and delivery time, the temporary closure of many shopping centers, enterprises in countries such as Russia, China, and Turkey, which are the leading importers of Uzbek textiles[8].

Despite the presence of the above problems, domestic light industry sectors in the first quarter not only maintained positive growth in production but also significantly increased their rates compared to the same period last year. According to the State Statistics Committee of the Republic of Uzbekistan, in the first quarter of this year, the production of textiles, clothing, leather products increased by $13.6 \%$ and amounted to 10.9 trillion sum. Of these, the production of textiles increased by $14.8 \%$ (in the 1 st quarter of 2019 , the growth was $1.3 \%$ ), clothing - by $11.1 \%(5.1 \%$ ), leather and leather products - by $10,6 \%(2.7 \%)[9]$.

In addition, despite all the difficulties in foreign trade, in the first quarter of 2020, the export of textiles and garments and knitwear increased by $25.5 \%$ compared to the same period last year and amounted to $\$ 463.5$ million. 57\%) fell on the CIS countries - \$265.7 million, an increase of $36.1 \%$. Exports to other countries increased by $13.6 \%$ and amounted to $\$$ 197.8 million.

Thus, the first months of the pandemic did not lead to significant negative consequences for the light industry of Uzbekistan, despite the difficulties with the delivery of goods and equipment necessary for the production and implementation of investment projects, with the arrival of foreign specialists [10].

\section{Conclusion}

To bring this paper to a close, I summarize the main highlights here: the first economic quarter has not caused significant damages to Uzbekistan's socio-economic activity in the areas such as automobile and textile production while the country's tourism industry received the hardest hit from a global economic crisis caused by the novel coronavirus (Covid-19).

\section{References}

[1] Bank, W. (2020, April 09). Europe and Central Asia Economic Update, Spring 2020. Retrieved July 16, 2020, from https://openknowledge.worldbank.org/handle/10986/33476

[2] R. (n.d.). Экспортные ориентиры Узбекистана. Retrieved July 19, 2020, from https://review.uz/ru/post/eksportne-orientir-uzbekistana

[3] S. (2020, March 19). Президент Узбекистана обратился к народу из-за пандемии COVID-19 - видео. Retrieved July 19, 2020, from https://uz.sputniknews.ru/politics/20200318/13708662/PrezidentUzbekistana-obratilsya-k-narodu-iz-za-pandemii-COVID-19.html

[4] Trade falls steeply in first half of 2020. (n.d.). Retrieved July 16, 2020, from https://www.wto.org/english/news_e/pres20_e/pr858_e.htm

[5] User, S. (n.d.). ВЫБОРОЧНЫЕ ОБСЛЕДОВАНИЯ за 1-квартал 2020 года. Retrieved July 19, 2020, from https://stat.uz/ru/450-dlya-predprinimatelej2/2191-vyborochnye-obsledovaniya2

[6 Исмаилова, А. (n.d.). Компания "Узавтосаноат" намерена к 2022 году довести уровень локализации оборудования и сырья до 70\%. Retrieved July 19, 2020, from https://podrobno.uz/cat/obchestvo/kompaniya-uzavtosanoat-namerena-k-2022-godu-dovesti-urovenlokalizatsii-oborudovaniya-i-syrya-do-70-/

[7] Srivastava, D. V., \& Tyagi, D. A. (2020). STUDY OVER STUDENT PERSONALITIES AND THE IMPACT OF EXTRINSIC FACTORS TO IMPROVE STUDENTS' ACADEMIC PERFORMANCE AND 


\section{MIDDLE EUROPEAN SCIENTIFIC BULLETIN}

EMPLOYABILITY. American Journal of Social and Humanitarian Research, 1(1), 40-50. Retrieved from https://www.grnjournals.us/index.php/AJSHR/article/view/20

[8] Обзор денежно-кредитной политики за I квартал 2020 года. (n.d.). Retrieved July 19, 2020, from https://cbu.uz/ru/monetary-policy/reviews/261572/

[9] Коронавирус инфекцияси (COVID-19). (n.d.). Retrieved July 16, 2020, from https://coronavirus.uz/

[10] Khosla, D. R., \& Kumar, M. (2020). IMPLEMENTATION AND IMPACT OF SARFAESI ACT 2002. American Journal of Social and Humanitarian Research, 1(1), 28-39. Retrieved from https://www.grnjournals.us/index.php/AJSHR/article/view/19 